\title{
Geo-Spatial Heat Index and Comfort Analysis of Port Harcourt City: An Approach to Environmental Health Care Delivery
}

\author{
Nwaerema Peace ${ }^{1}$, Bridget Edewede Diagi ${ }^{2} \&$ Ajiere Suzan $^{1}$ \\ ${ }^{1}$ Department of Geography and Environmental Management, University of Port Harcourt, Nigeria \\ ${ }^{2}$ Department of Environmental Management, Federal University of Technology, Owerri, Nigeria \\ Correspondence: Nwaerema Peace, Department of Geography and Environmental Management, University of Port \\ Harcourt, Nigeria. Tel: 234-803-267-8876. E-mail: pnwaerema486@gmail.com
}

Received: November 7, 2019 Accepted: December 7, 2019 Online Published: December 12, 2019

\begin{abstract}
This research examined the geo-spatial heat index and comfort analysis of Port Harcourt city as an approach to environmental health care delivery. Temperature data were generated from different land use types across days of the week in both wet (April to September) and dry (October to March) seasons. Heat index was derived when air temperature and dew point temperature of the locations were corresponded in the heat index chart or data logger calculator. Findings indicate that the city had experienced danger levels of discomfort above $41 \mathrm{oC}$ in the late dry season of January, February and March showing that heat cramps and heat exhaustion as well as heat stroke were probably to occur with continued activity of a person. On the other hand, early dry season of October, November and December had the best human comfort period of $<26.7 \mathrm{oC}$ temperature except Thursday and Friday with caution level of 27 to $32^{\circ} \mathrm{C}$ in the city of Port Harcourt; though fatigue was possible as prolonged exposure could result to heat cramps. High residential/commercial and administrative/industrial land uses had the highest human discomfort indicating that those living in these land use types would suffer extreme hazard of heat stroke. However, recreation and rural sites were the most comfortable land use types. Young children and old people are generally in more danger to the heat effects as the city has exceeded the $27 \mathrm{oC}$ thermal comfort threshold. It is therefore recommended that city planners and development practitioners should implement urban green policy of tree planting with special attention to residential/commercial and administrative/industrial areas without further delay in order to cushion the deadly menace of urban heat in Port Harcourt city and its environs.
\end{abstract}

Keywords: geo-spatial, temperature, heat index, land use type, caution level, danger level, health

\section{Introduction}

One of the greatest challenges facing cities across the world is rising temperature due to modification of biophysical components of the city surface areas by urban fabrics (Coseo and Larsen, 2014). The alteration of urban surface areas has resulted to the concept of Urban Heat Island (UHI). UHI occurs when temperature in a city rises above that of the extended rural outskirts in the urban canopy (Yow, 2007). This temperature rise is as a result of rapid population and urbanization with the attendant UHI effect that is making several cities become very uncomfortable to live due to its impact on Heat Index (HI) and economy (Stewart, 2011; Stone, 2012). Heat Index also known as humiture is an index that associates air temperature and dew point temperature or relative humidity of shaded areas to suggest human perceived corresponding temperature on how hot people would feel if the dew point temperature or humidity values vary in shaded areas (Brooke, Michelle and Roger, 2013). Heat index is the apparent temperature which measures how hot it really feels when dew point temperature or relative humidity is factored with the actual air temperature. This temperature is known to be the felt air temperature, apparent temperature and real feel of temperature of the environment. The heat index expresses the level of comfort or stress provided by a given area (Ketterer and Matzarakis, 2014).

Air temperature is a measure of how hot or cold the air is at a given time; and relative humidity is a measure of the amount of water (moisture) in the air as compared to the maximum amount of water the air can absorb usually expressed in percentage. When air cannot absorb any more moisture, it is said to be fully saturated; it means that its relative humidity is 100 percent (Tawhida and Hisham, 2013). On the other hand, dew point is the temperature at which a given volume of air at certain atmospheric pressure is saturated with water vapor, causing condensation and the formation of dew, which is the condensed water seen on flowers and grasses early in the morning. Furthermore, the higher the relative humidity, the closer the dew point to the current air temperature. When dew 
point is below freezing $\left(0^{\circ} \mathrm{C}\right.$ or $\left.32^{\circ} \mathrm{F}\right)$, the water vapor turns directly into frost rather than dew (Sarah, Lee, Kate, Phong, Lan and Phuong, 2016). Thus, Harlan, Brazel, Prashad, Stefanov and Larsen (2006) concluded that dew point temperature and humidity are key variables that influence thermal comfort of a city; and they are prospective tools in weather forecast used to express the amount of moisture in the air.

Generally, when the ambient air temperature is above the comfort threshold, it will result to heat cramp, respiratory problems, heat stroke and eventual death as well as loss of economic growth (Nwaerema, Ologunorisa, Nwagbara and Ojeh, 2019; World Health Organization [WHO] 2007). High temperature can impair quality of water bodies which could result to the death of aquatic life and food shortages (United States Environmental Protection Agency [USEPA] (2007). In addition, the demand for energy will continuously increase with rise in UHI and accelerated heat index. For instance $0.6^{\circ} \mathrm{C}$ rise in temperature will result to $2 \%$ energy demand and $10 \%$ of global energy demand is used to compensate for heat island (James, 2002).

Extreme rise in temperature has resulted to Heat Waves (HWs) leading to death of people, animals and other living things (World Health Organization [WHO] 2007). Heat wave will result to loss of work hours, high electric power consumption and rise in pollutant reaction (World Health Organization [WHO] 2007; United States Environmental Protection Agency [USEPA] 2007; James, 2002; Center for Disease Control and Prevention [CDCP] 2006). Temperature, humidity, intensity of wind speed as well as type of clothing affects level of comfort of city dwellers. The type of physical activities engaged by a person under a given environmental condition will influence the stress and comfort level. Many scientists have carried out biometeorology of the environment over the years with a welldeveloped heat and stress indices for human comfort (Sushil, Sagnik, Popat, Mamta, Vaishali, Sourangsu and Rohit, 2017).

However, daily anthropogenic activities have caused urban heat budget variation in Port Harcourt space. Climatic parameters vary from season to season and across different local climatic zones. Different land use types have their identical homogenous biophysical characteristics of urban pavement materials and vegetal cover as well as water bodies. Wind speed varies across the canopy layer according to the urban relief system resulting to variation in the city energy distribution. In the same vein, temperature spread has effect on the heat index in seasons and days of the week. Accordingly, it becomes expedient to investigate the geo-spatial variation of heat index with the trend of mass movement of people and alteration of biophysical space of Port Harcourt metropolis and environs.

\section{Method}

Port Harcourt is a coastal settlement located in the Niger Delta region of Nigeria with Latitudes of $4^{\circ} 05^{\prime} 30^{\prime}$ ' $\mathrm{N}$ and $5^{\circ} 14^{\prime} 25^{\prime}$ ' $\mathrm{N}$ and Longitudes 5 $40^{\prime} 30^{\prime \prime} \mathrm{E}$ and $7^{\circ} 11^{\prime} 01^{\prime}{ }^{\prime} \mathrm{E}$ Greenwich Meridian (Figure 1). The soil is dominated with sedimentary formation. As a coastal city close to the Atlantic Ocean, the atmospheric characteristics are influenced by the monsoon climate. The wind flow system is derived from the marine and land breezes to the inland city (Nwaerema, Ojeh, Amadou and Atuma, 2019). At continental scale Port Harcourt climate is modified by the continental air mass from the north-easterly winds in the Inter-Tropical Convergence Zone (ITCZ). Rainfall volume ranges between $2000 \mathrm{~mm}$ to $2500 \mathrm{~mm}$ favoring the months of April to October (Chiadikobi Omoboriowo, Chiaghanam, Opatola, and Oyebanji, 2011). Relative humidity rises from April to September with peaks in July and a sharp drop in January to March (Nwaerema and Nwagbara, 2018). Port Harcourt experiences high temperature from January till March; within this period relative humidity is low. Temperature up to $32^{\circ} \mathrm{C}$ is common during the dry season and lowest of $26^{\circ} \mathrm{C}$ is noticeable in July (Edokpa and Nwagbara, 2017). Annual humidity value is $85 \%$ in the wet season and cloud cover is 6 oktas during the wet season with low trend in the dry season (Nwaerema et. al. 2019; Chiadikobi, 2017). Mean wind speed is between 0-3m/s capable of influencing urban heat and weak wind speed will accelerate thermal discomfort of the city especially during nocturnal hours (Shaibu and Utang, 2013; Nwaerema and Nwagbara, 2018; Nwaerema and Edokpa, 2019). Heat index is characterized by coastal climatic conditions as they impact on human comfort and health. 


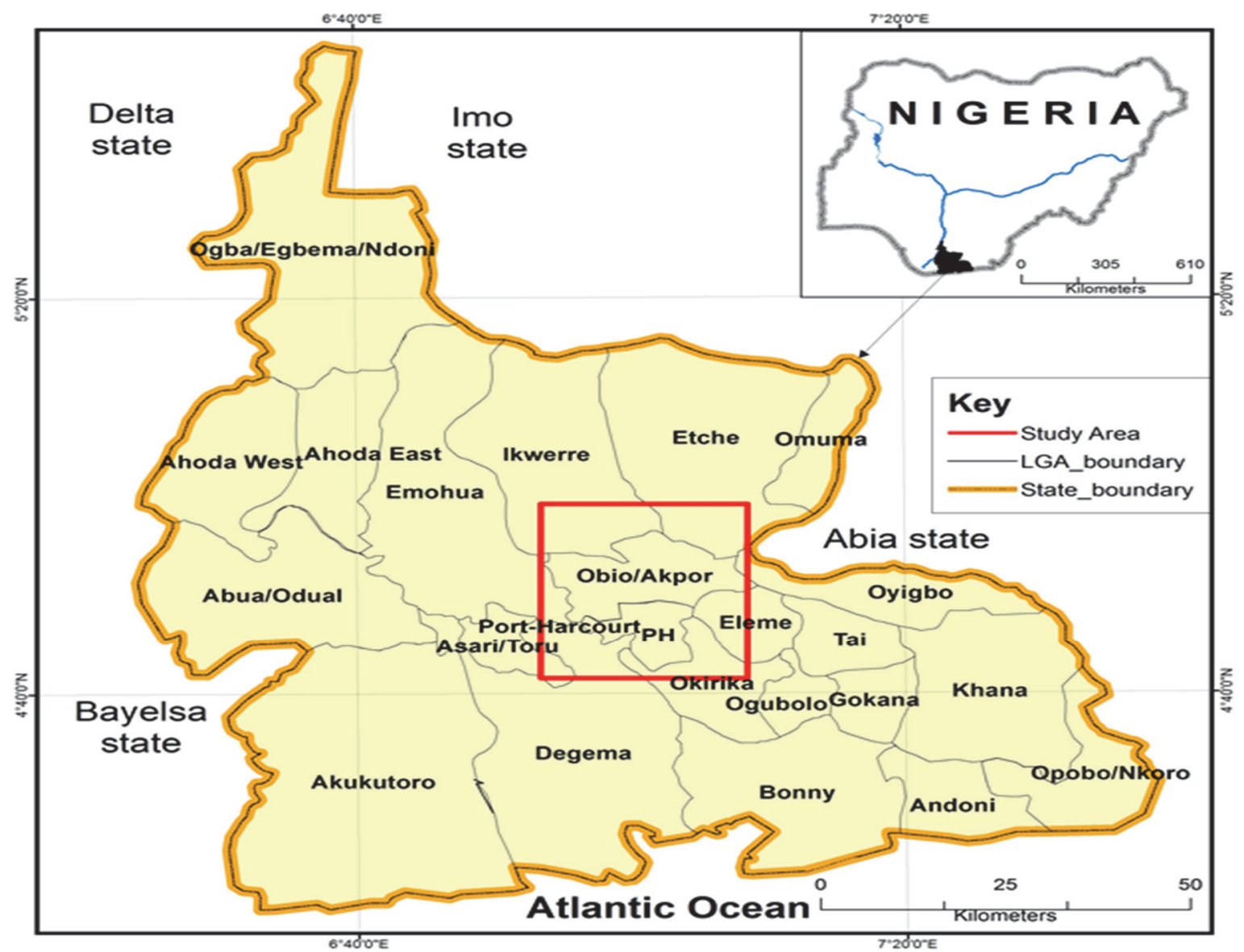

Figure 1. Port Harcourt Metropolis and Environs

Temperature and dew point temperature data as the key drivers of heat index were measured and computed for 12 months in wet and dry seasons: April, May and June (AMJ, as early wet season), July, August and September (JAS, as late wet season), October, November, and December (OND, as early dry season) and January, February and March (JFM, as late dry season) in 2017/2018 at 0006 (Morning), 1200 (Afternoon) and 1800 (Evening) hours accordingly. The data sets were organized according to daily averages in days of the week in wet and dry months. Temperature data were observed using LCD Digital Multi-Thermometer Loggers placed in delineated land surfaces (35 sample points) on the selected hours in the days of the week in wet and dry seasons (Figure 2). Field assistants from private homes and business areas took the measurements simultaneously. The thermometers were Handheld Digital devices with ST9269 model and St-9283B/St-9269B, factory-made by MEXTECH. Resolutions were of $0.1^{\circ} \mathrm{C}\left(0.2^{\circ} \mathrm{F}\right)$ with measuring range of $-500 \mathrm{C}$ to $3000 \mathrm{C}(-580 \mathrm{~F}-5720 \mathrm{~F})$ at St-9283B and $-500 \mathrm{C}$ to $2000 \mathrm{C}$ $(-580 \mathrm{~F}-3720 \mathrm{~F})$ at St-9269B respectively. The accuracy constant was $\pm 10 \mathrm{C}$, ranging $-500 \mathrm{C}$ to $1500 \mathrm{C}( \pm 20 \mathrm{~F}$ in the range of $-220 \mathrm{~F}$ to $3020 \mathrm{~F}$ ). Error readings were very minimal as measurements were approximately at the height of a head, 1.5 meter above the ground in the canopy layer. Homogenous purposive sampling technique was adopted based on homogeneity and shared characteristic of delineated land categories. Finally heat index was derived when air temperature and dew point temperature of the locations were corresponded in the heat index chart or data logger calculator (Table 2). Heat index was also derived by computing air temperature and relative humidity using the heat index chart or data logger calculator. The computation of heat index is obtained by multiple regression analysis programmed in the calculator and the data logger (Brooke, Michelle and Roger, 2013; National Centre for Environmental Prediction [NCEP], 2018; Anderson and Peng, 2012).

The dew point temperature (Td) was derived using the dew point calculator, by keying the temperature data, the dew point calculator associates and estimates temperature for which air must be cool at a given temperature reading (Calculator.net, 2018; Dpcalc.org, 2018). Dew point is closely related with relative humidity, one of them can be used along with air temperature to estimate heat index of an area (Mark, 2005). Also, temperature in degree Celsius $\left({ }^{\circ} \mathrm{C}\right)$ was converted to degree Fahrenheit $\left({ }^{\circ} \mathrm{F}\right)\left[\left(0^{\circ} \mathrm{C}\right.\right.$ x $\left.\left.9 / 5\right)+32=32^{\circ} \mathrm{C}\right]$ and applied in the Heat Index (HI) chart (Table 2) as the standard humiture table for heat index studies. The temperatures in Celsius were converted to 
Fahrenheit to correspond to the standard humiture in Fahrenheit for consistency and accuracy as well as better analysis of results. The humiture is already existing standard reference table for heat index studies provided by heat index experts used for humiture analysis. Temperature effects of heat index were corresponded to the various temperature readings of caution, extreme caution, danger and extreme danger in the analysis (Table 3).

Heat index is the apparent temperature which measures how hot it really feels when dew point temperature or relative humidity is factored with the actual air temperature. This temperature is known to be the felt air temperature, apparent temperature and real feel of temperature of the environment. The heat index expresses the level of comfort or stress provided by a given area.

While perception varies among people, some people at some level can acclimatize to high dew points while high dew points are generally uncomfortable because the humidity inhibits proper evaporation of sweat, making it more difficult for a person's body to cool. Conversely, lower dew points can also be uncomfortable, causing skin irritation and cracking as well as drying out a person's airways. It is recommended that outdoor temperatures be maintained between $70-80^{\circ} \mathrm{F}\left(21-27^{\circ} \mathrm{C}\right)$ with relative humidity of $25-60 \%$ (Andre, João, Mattheos and Andreas, 2018; Wendell, 2015; U.S. National Oceanic and Atmospheric Administration [NOAA], 2019).

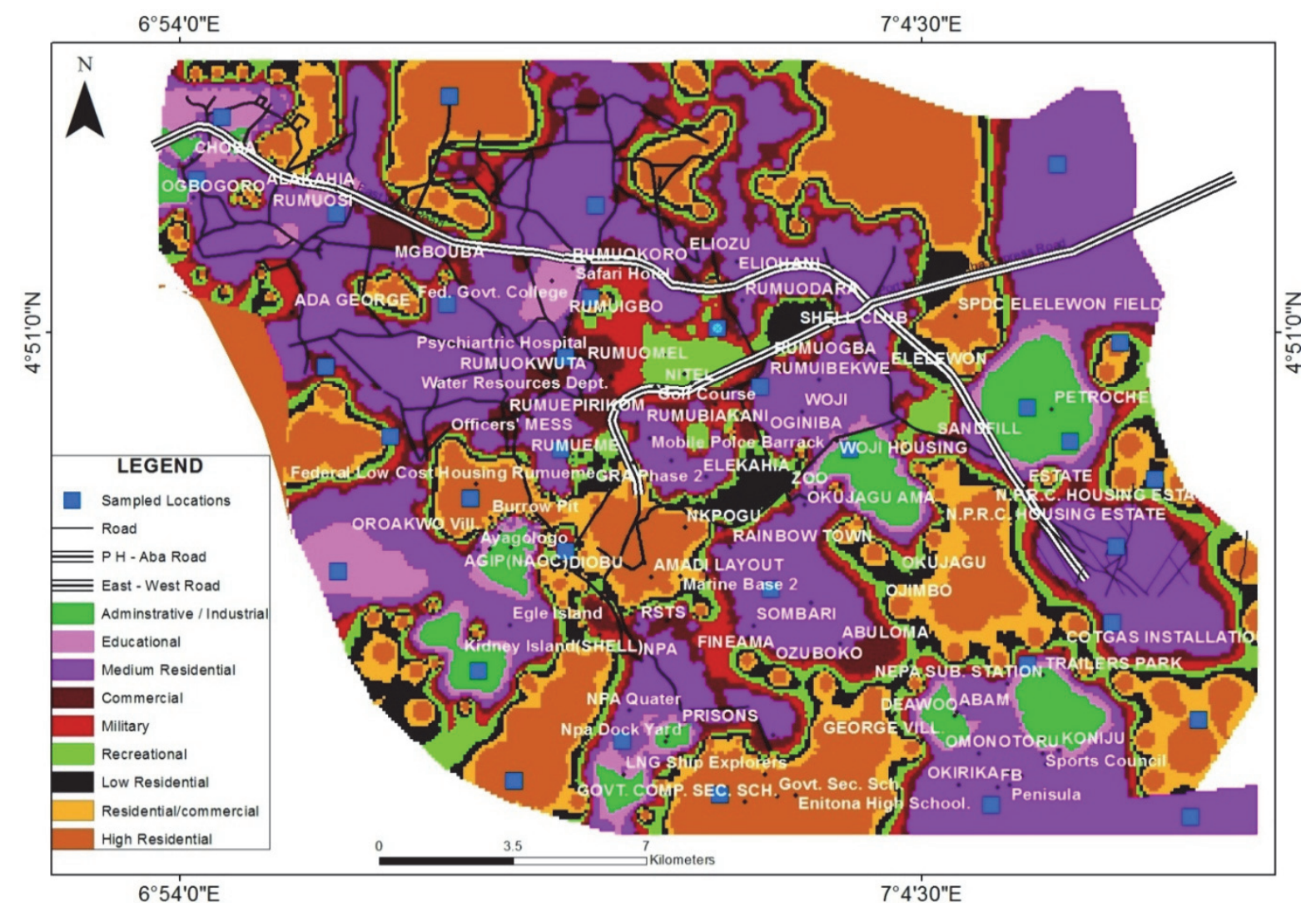

Figure 2. Port Harcourt Land Use Types

Table 1. Land Use/Built-up Area and Locations

\begin{tabular}{ll}
\hline Land use/built-up & \multicolumn{1}{c}{ Location } \\
\hline \multirow{2}{*}{ Low Residential } & Eleme, GRA, Intel zone, Total Estate, Oyibo, Shell estate, Bolokiri, Igwuruta, Etche, \\
& Iwofe, Jetty, Choba, Elelenwo, Okirika, Rumosi, Elekahia, Mgbuoba,Eagle Island. \\
High Residential & Diobu, D-Line,Enitona School Area \\
Medium Residential & Ada-George, Abloma, Rumuigbo, Port Harcourt Township, Rumuola, Choba, Mgbuoba, \\
& Woji, Okirika, Rumuodara \\
Educational & University of Port Harcourt, University of Science and Technology, Port Harcourt Poly
\end{tabular}


Technique, Ignatious Ajuru University

Commercial

Military

Recreational

Residential/Commercial

Admin/Industrial
Mile One market, Rumuokoro Market, Mile 3 Market, Slaughter, Ikoku market,Oil Mill Market

Navy barracks, Bori Camp, Airforce

Boro Park, Port Harcourt Tourist, Rainbow Zoo, Port Harcourt Pleasure Park, Woji Housing

Orazi, Rumuokwurusi, Rumuaghorlu, Rumuibekwe, Rumuodomaya, Ogbunabali, Rukpoku, Rumuokwuta

Eleme Petrochemical area,Marine Base, BMH, UPTH, Transamadi, Agip, NPA, Rivers State Secretariat.

\begin{tabular}{lll}
\hline Rural & Elibrada, Aleto, Dankiri, Obeta, Omagwa (control sites) \\
\hline
\end{tabular}

Source: Author, 2018.

Table 2. Heat Island Index Chart using Air Temperature and Dew Point Temperature Data

\begin{tabular}{|c|c|c|c|c|c|c|c|c|c|c|c|c|c|c|c|c|c|c|c|c|c|c|}
\hline & \multicolumn{21}{|c|}{ AIR TEMPERATURE ( $\left.{ }^{\circ} \mathrm{F}\right)$} \\
\hline & & 80 & 82 & 84 & 86 & 88 & 90 & 92 & 94 & 96 & 98 & 100 & 102 & 104 & 106 & 108 & 110 & 112 & 114 & 116 & 118 & 120 \\
\hline \multirow{16}{*}{ 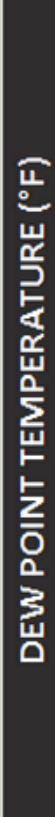 } & 60 & 81 & 83 & 85 & 87 & 89 & 91 & 93 & 95 & 97 & 99 & 102 & 104 & 106 & 108 & 111 & 113 & 115 & 117 & 119 & 121 & 123 \\
\hline & 62 & 82 & 83 & 85 & 87 & 89 & 92 & 94 & 96 & 98 & 101 & 103 & 105 & 107 & 110 & 112 & 114 & 116 & 119 & 121 & 123 & 125 \\
\hline & 64 & 82 & 84 & 86 & 88 & 90 & 93 & 95 & 97 & 99 & 102 & 104 & 107 & 109 & 111 & 113 & 116 & 118 & 120 & 122 & 124 & 127 \\
\hline & 66 & 83 & 85 & 87 & 89 & 91 & 94 & 96 & 98 & 101 & 103 & 106 & 108 & 110 & 113 & 115 & 117 & 120 & 122 & 124 & 126 & 128 \\
\hline & 68 & 83 & 85 & 88 & 90 & 92 & 95 & 97 & 100 & 102 & 105 & 107 & 110 & 112 & 115 & 117 & 119 & 122 & 124 & 126 & 128 & 130 \\
\hline & 70 & 84 & 86 & 89 & 91 & 94 & 96 & 99 & 101 & 104 & 107 & 109 & 112 & 114 & 116 & 119 & 121 & 124 & 126 & 128 & 130 & 132 \\
\hline & 72 & 85 & 87 & 90 & 93 & 95 & 98 & 101 & 103 & 106 & 109 & 111 & 114 & 116 & 119 & 121 & 123 & 126 & 128 & 130 & 133 & 135 \\
\hline & 74 & 86 & 88 & 91 & 94 & 97 & 100 & 102 & 105 & 108 & 111 & 113 & 116 & 119 & 121 & 124 & 126 & 128 & 131 & 133 & 135 & 137 \\
\hline & 76 & 87 & 90 & 93 & 96 & 99 & 102 & 105 & 108 & 110 & 113 & 116 & 119 & 121 & 124 & 126 & 129 & 131 & 133 & 136 & 138 & 140 \\
\hline & 78 & 89 & 92 & 95 & 98 & 101 & 104 & 107 & 110 & 113 & 116 & 119 & 121 & 124 & 127 & 129 & 132 & 134 & 137 & 139 & 141 & 143 \\
\hline & 80 & 90 & 94 & 97 & 100 & 103 & 107 & 110 & 113 & 116 & 119 & 122 & 125 & 127 & 130 & 133 & 135 & 138 & 140 & 142 & 144 & 147 \\
\hline & 82 & & 96 & 99 & 103 & 106 & 110 & 113 & 116 & 119 & 122 & 125 & 128 & 131 & 134 & 136 & 139 & 141 & 144 & 146 & 148 & 150 \\
\hline & 84 & & & 103 & 106 & 110 & 113 & 117 & 120 & 123 & 126 & 129 & 132 & 135 & 138 & 140 & 143 & 145 & 148 & 150 & 152 & 155 \\
\hline & 86 & & & & 110 & 114 & 117 & 121 & 124 & 127 & 131 & 134 & 137 & 140 & 142 & 145 & 148 & 150 & 152 & 155 & 157 & 159 \\
\hline & 88 & & & & & 118 & 122 & 125 & 129 & 132 & 136 & 139 & 142 & 145 & 147 & 150 & 153 & 155 & 157 & 160 & 162 & 164 \\
\hline & 90 & & & & & & 127 & 131 & 134 & 138 & 141 & 144 & 147 & 150 & 153 & 156 & 158 & 161 & 163 & 165 & 167 & 169 \\
\hline
\end{tabular}

Key to colors: $\square$ Caution $\square$ Extreme caution $\square$ Danger $\square$ Extreme danger

Source: Wendell, 2015

Table 3. Effects of Various Heat Island Index Scores

\begin{tabular}{lll}
\hline Celsius & Fahrenheit & Notes \\
\hline$<27^{\circ} \mathrm{C}$ & $80^{\circ} \mathrm{F}$ & $\begin{array}{l}\text { Comfort: Bodily and psychological thermal comforts are possible. Heat } \\
\text { cramp, thermal exhaustion and heat stroke are relatively limited. }\end{array}$ \\
$27-32^{\circ} \mathrm{C}$ & $80-90^{\circ} \mathrm{F}$ & $\begin{array}{l}\text { Caution: fatigue is possible with prolonged exposure and activity. Continuing } \\
\text { activity could result in heat cramps. }\end{array}$ \\
$32-41^{\circ} \mathrm{C}$ & $90-105^{\circ} \mathrm{F}$ & $\begin{array}{l}\text { Extreme caution: heat cramps and heat exhaustion are possible. Continuing } \\
\text { activity could result in heat stroke. }\end{array}$ \\
\hline
\end{tabular}




\begin{tabular}{lll}
\hline $41-54^{\circ} \mathrm{C}$ & $105-130^{\circ} \mathrm{F}$ & $\begin{array}{l}\text { Danger: heat cramps and heat exhaustion are likely; heat stroke is probable } \\
\text { with continued activity. }\end{array}$ \\
$>54^{\circ} \mathrm{C}$ & $>130^{\circ} \mathrm{F}$ & Extreme danger: heat stroke is imminent. \\
\hline
\end{tabular}

Source: US National Oceanic and Atmospheric Administration (NOAA), 2019

\section{Results}

During the early wet season of April, May and June (Table 4), $75 \%$ of the period was within heat index caution level $\left(27-32^{\circ} \mathrm{C}\right)$ and $24.3 \%\left(32-41^{\circ} \mathrm{C}\right)$ under extreme caution level indicating that heat cramps and heat exhaustion were possible. It showed that continuing activities could result to heat stroke especially those located in mixed residential/commercial, administrative/industrial and medium residential areas respectively. On the average, all land use types had caution level heat index except residential/commercial land use with extreme caution level. Residents in educational, recreational and rural sites had better comfort level with less heat hazard. Also, beginning of the week such as Monday, Tuesday and Wednesday had severe effect of the urban heat index. Differences in temperatures across days of the week and land use types is as a result of variations in anthropogenic activities across days of the week and mixed distribution of vegetation, water bodies, urban fabrics and climatic parameters across the various land use types. The heat index during this period was unlikely compared to the high heat index of Porto in July 2006 which recorded excess of 107 deaths at 52\% increment characterized by very high temperatures of $29^{\circ} \mathrm{C}$ to $37^{\circ} \mathrm{C}$ and relative humidity of $42 \%$ to $71 \%$ (Monteiro, Carvalho, Velho and Sousa, 2011).

Table 4. Heat Index (Temperature in 0F) of Early Wet Season (April May and June)

\begin{tabular}{cccccccccccc}
\hline $\begin{array}{c}\text { Days/Land } \\
\text { Use }\end{array}$ & Rural & Military & $\begin{array}{c}\text { Admn/ } \\
\text { Indust. }\end{array}$ & $\begin{array}{c}\text { High } \\
\text { Res. }\end{array}$ & $\begin{array}{c}\text { Res/ } \\
\text { Comer. }\end{array}$ & $\begin{array}{c}\text { Med } \\
\text { Res. }\end{array}$ & $\begin{array}{c}\text { Commer. } \\
\text { Low }\end{array}$ & $\begin{array}{c}\text { Educt. } \\
\text { Res. }\end{array}$ & Recreat. \\
\hline Mon & 84 & 87 & 90 & 88 & 102 & 91 & 90 & 90 & 83 & 82 & 81 \\
Tues & 84 & 90 & 92 & 92 & 98 & 90 & 90 & 83 & 87 & 81 & 83 \\
Wed & 83 & 83 & 92 & 89 & 96 & 88 & 88 & 83 & 88 & 81 \\
Thurs & 85 & 81 & 83 & 88 & 92 & 85 & 63 & 63 & 83 & 81 \\
Fri & 83 & 89 & 89 & 88 & 95 & 89 & 91 & 85 & 85 & 83 \\
Sat & 83 & 81 & 83 & 85 & 89 & 81 & 89 & 83 & 89 & 83 \\
Sun & 62 & 83 & 83 & 86 & 95 & 88 & 83 & 83 & 81 & 81 \\
Mean & 83 & 83 & 86 & 88 & 95 & 86 & 86 & 83 & 85 & 81 \\
\hline
\end{tabular}

Author, 2018.

In the late wet season of July, August and September (Table 5), 75\% of the period was within heat index caution level $\left(27-32^{\circ} \mathrm{C}\right), 17.1 \%\left(32-41^{\circ} \mathrm{C}\right)$ under extreme caution level and $5.7 \%\left(<26.7^{\circ} \mathrm{C}\right)$ was under comfort threshold indicating that heat cramps and heat exhaustion were possible. The late wet season was relatively cooler than the early wet season. However, the period showed that continuing activities could result to heat stroke especially those located in mixed residential/commercial, administrative/industrial and educational sites. On the average, all land use types were under caution level heat index during the period. Residents in educational, recreational, high residential and administrative/industrial areas experienced some form of comfort on Mondays and Thursdays during the period. Generally the period exceeded the comfort threshold except few days of the week. Studies conducted by Ponni and Baskar (2015) and Ana, Vania, Sara and Carlos, (2013) on apparent temperature in daily mortality verified that during a hot season when the comfort level is exceeded the increase of $1^{\circ} \mathrm{C}$ in daily average apparent temperature will result to the increase of $2.7 \%$ in respiratory causes for mortality. 
Table 5. Heat Index (Temperature in ${ }^{0} \mathrm{~F}$ ) of Late Wet Season (July, August and September)

\begin{tabular}{lccccccccccc}
$\begin{array}{l}\text { Days/Land } \\
\text { Use }\end{array}$ & Rural & Military & $\begin{array}{c}\text { Admn/ } \\
\text { Indust. }\end{array}$ & $\begin{array}{c}\text { High } \\
\text { Res. }\end{array}$ & $\begin{array}{c}\text { Res/ } \\
\text { Comer. }\end{array}$ & $\begin{array}{c}\text { Med } \\
\text { Res. }\end{array}$ & Commer. & $\begin{array}{c}\text { Low } \\
\text { Res. }\end{array}$ & Educt. & Recreat. \\
\hline Mon & 83 & 83 & 85 & 83 & 99 & 88 & 86 & 85 & 83 & $<80$ \\
Tues & 83 & 89 & 92 & 88 & 96 & 89 & 88 & 63 & 89 & 81 \\
Wed & 85 & 83 & 92 & 89 & 90 & 88 & 88 & 85 & 92 & 86 \\
Thurs & 85 & 83 & $<80$ & $<80$ & 89 & 81 & 81 & 83 & $<80$ & $<80$ \\
Fri & 83 & 92 & 85 & 86 & 99 & 88 & 88 & 85 & 88 & 83 \\
Sat & 85 & 86 & 88 & 88 & 95 & 85 & 89 & 85 & 92 & 83 \\
Sun & 85 & 83 & 85 & 88 & 96 & 91 & 89 & 83 & 81 & 81 \\
Mean & 85 & 86 & 85 & 85 & 95 & 86 & 86 & 85 & 86 & 81 \\
\hline
\end{tabular}

Author, 2018

Early dry season (October, November and December) (Table 6) was the coolest period of the year with relatively comfortable heat index level. All days of the week experienced relative comfort $\left(<26.7^{\circ} \mathrm{C}\right)$ except Thursday and Friday with caution level of $\left(27-32^{\circ} \mathrm{C}\right)$ expressing the view that heat cramp and fatigue were possible with extended exposure to heat. Greater part of land uses had good comfort threshold except administrative/industrial, high residential, residential/commercial and medium residential areas. On the average, recreational and rural areas maintained moderate comfort threshold throughout the period. Monday, Tuesday and Wednesday had relatively better comfort heat index level during the season. Recreational land use had the best heat index level during the period. There was absence of extreme caution heat index level during this season indicating that the people in the area had lesser heat cramps, exhaustion and heat stroke due to the present of the harmattan season. The climate location and air velocity influence level of thermal comfort of a place. However, studies have established proposed operative temperatures and wind velocities ranging from $0.4 \mathrm{~m} / \mathrm{s}$ for $24-27^{\circ} \mathrm{C}, 0.41-0.8 \mathrm{~m} / \mathrm{s}$ for $27-29^{\circ} \mathrm{C}$, and 0.81 $\mathrm{m} / \mathrm{s}$ for $29-31{ }^{\circ} \mathrm{C}$ for human comfort in the country considering the influence of wind velocity on thermal performance (Ana et al, 2013; Almeida, Casimiro and Calheiros, 2010, Candido, deDear and Lamberts, 2011). In this vein, the harmatan season accelerates wind velocity in this period thereby moderating the thermal performance of Port Harcourt city for human comfort.

Table 6. Heat Index (Temperature in ${ }^{0} \mathrm{~F}$ ) of Early Dry Season (October, November and December)

\begin{tabular}{ccccccccccc}
$\begin{array}{c}\text { Days/Land } \\
\text { Use }\end{array}$ & Rural & Military & $\begin{array}{c}\text { Admn/ } \\
\text { Indust. }\end{array}$ & $\begin{array}{c}\text { High } \\
\text { Res. }\end{array}$ & $\begin{array}{c}\text { Res/ } \\
\text { Comer. }\end{array}$ & $\begin{array}{c}\text { Med } \\
\text { Res. }\end{array}$ & Commer. & $\begin{array}{c}\text { Low } \\
\text { Res. }\end{array}$ & Educt. & Recreat. \\
\hline Mon & $<80$ & $<80$ & 81 & $<80$ & 86 & 81 & $<80$ & $<80$ & $<80$ & $<80$ \\
Tues & $<80$ & 88 & 83 & 83 & 86 & 82 & 82 & $<80$ & $<80$ & $<80$ \\
Wed & $<80$ & $<80$ & 83 & 81 & 86 & $<80$ & $<80$ & $<80$ & $<80$ & $<80$ \\
Thurs & 83 & 83 & 81 & 86 & 89 & 83 & 81 & 81 & 83 & 81 \\
Fri & 81 & 85 & 85 & 83 & 80 & 85 & 85 & 82 & 81 & $<80$ \\
Sat & 81 & $<80$ & 81 & 81 & 85 & $<80$ & 83 & 81 & 85 & $<80$ \\
Sun & 81 & $<80$ & $<80$ & 83 & 88 & 83 & 81 & $<80$ & $<80$ & $<80$ \\
Mean & $<80$ & 81 & 81 & 81 & 86 & 81 & 81 & $<80$ & 81 & $<80$ \\
\hline
\end{tabular}

Author, 2018

The late dry season (January, February and March) (Table 7) had the most uncomfortable heat index with caution, extreme caution and danger levels. In the late dry season, $2.9 \%$ of the period had heat index caution level (27$\left.32^{\circ} \mathrm{C}\right), 75.7 \%\left(32-41^{\circ} \mathrm{C}\right)$ under extreme caution level and $21.4 \%\left(41-54^{\circ} \mathrm{C}\right)$ lay within the danger level indicating that heat cramps, exhaustion and heat stroke were very possible. It showed that continuing activities could result to heat stroke in medium residential, commercial, military and educational land uses with greatest effect on 
residential/commercial and administrative/industrial land uses. Only recreational site had heat index caution level $\left(27-32^{\circ} \mathrm{C}\right)$ during the period. This period had Temperature below caution level of $<26.7^{\circ} \mathrm{C}$ was very rare indicating that the period experience intense and dangerous hot weather. All days of the week had dangerous heat index level with increment on Tuesday and Friday followed by days of Monday, Wednesday and Saturday. Also, beginning of the week such as Monday, Tuesday and Wednesday had severe effect of the urban heat index as well as Friday later part of the week. The thermal comfort of a person is the condition of mind which expresses satisfaction with the thermal environment which the body must be maintained at $37^{\circ} \mathrm{C}$ [40]. Insufficient heat loss to the body results to body overheating (hyperthermia) and excessive heat loss from the body leads to body overcooling (hypothermia). This period has explicit expression of high heat index values (extreme caution and danger levels) capable of altering the acceptable body temperature of $37^{\circ} \mathrm{C}$ making the season very uncomfortable for the city Port Harcourt city dwellers (Ronald, William and Harry, 2010; Khaled, 2011; Edokpa and Nwaerema, 2019).

Table 7. Heat Index (Temperature in ${ }^{0} \mathrm{~F}$ ) of Late Dry Season (January, February and March)

\begin{tabular}{|c|c|c|c|c|c|c|c|c|c|c|}
\hline $\begin{array}{c}\text { Days/Land } \\
\text { Use }\end{array}$ & Rural & Military & $\begin{array}{l}\text { Admn/ } \\
\text { Indust. }\end{array}$ & $\begin{array}{l}\text { High } \\
\text { Res. }\end{array}$ & $\begin{array}{c}\text { Res/ } \\
\text { Comer. }\end{array}$ & $\begin{array}{l}\text { Med } \\
\text { Res. }\end{array}$ & Commer. & $\begin{array}{l}\text { Low } \\
\text { Res. }\end{array}$ & Educt. & Recreat. \\
\hline Mon & 99 & 99 & 105 & 99 & 113 & 103 & 99 & 103 & 92 & 89 \\
\hline Tues & 96 & 103 & 102 & 95 & 119 & 105 & 105 & 92 & 101 & 89 \\
\hline Wed & 99 & 95 & 108 & 103 & 101 & 101 & 101 & 96 & 99 & 96 \\
\hline Thurs & 99 & 96 & 92 & 103 & 108 & 99 & 92 & 92 & 96 & 91 \\
\hline Fri & 96 & 105 & 105 & 103 & 113 & 105 & 108 & 99 & 99 & 95 \\
\hline Sat & 99 & 91 & 96 & 99 & 103 & 92 & 96 & 92 & 103 & 92 \\
\hline Sun & 96 & 92 & 92 & 99 & 109 & 99 & 96 & 92 & 91 & 90 \\
\hline Mean & 99 & 96 & 99 & 103 & 113 & 99 & 101 & 95 & 91 & 91 \\
\hline
\end{tabular}

Author, 2018

During the year under study (Table 8), the mean temperature analysis showed that caution and extreme caution heat index levels were paramount indicating that residents of Port Harcourt metropolis and environs had exceeded the heat comfort threshold where fatigue, heat cramps, exhaustion and heat stroke were common health hazards prevalent in the area especially those residing in sites mixed with both resident houses, commercial buildings and beginning part of the week.

Table 8. Annual Heat Index (Temperature in $\left.{ }^{0} \mathrm{~F}\right)$

\begin{tabular}{lcccccccccccc}
\hline & Rural & Milit. & $\begin{array}{c}\text { Admn/ } \\
\text { Indust. }\end{array}$ & $\begin{array}{c}\text { High } \\
\text { Res. }\end{array}$ & $\begin{array}{c}\text { Res/ } \\
\text { Comer. }\end{array}$ & $\begin{array}{c}\text { Med } \\
\text { Res. }\end{array}$ & Comm. & $\begin{array}{c}\text { Low } \\
\text { Res. }\end{array}$ & Educt. & $\begin{array}{c}\text { Recreat. } \\
\text { Mean } \\
\text { Temp }\end{array}$ \\
\hline Mon & 85 & 85 & 89 & 86 & 99 & 89 & 85 & 85 & 83 & 81 & 86 \\
Tues & 85 & 91 & 91 & 91 & 99 & 89 & 89 & 87 & 88 & 83 & 89 \\
Wed & 85 & 83 & 92 & 69 & 96 & 88 & 88 & 85 & 89 & 85 & 88 \\
Thurs & 88 & 88 & 83 & 88 & 95 & 86 & 85 & 85 & 85 & 83 & 86 \\
Fri & 86 & 89 & 92 & 89 & 99 & 91 & 91 & 88 & 88 & 86 & 83 \\
Sat & 82 & 83 & 86 & 88 & 92 & 83 & 91 & 85 & 89 & 83 & 86 \\
Sun & 86 & 85 & 83 & 89 & 96 & 89 & 85 & 81 & 83 & 83 & 86 \\
Mean & 86 & 86 & 88 & 89 & 96 & 85 & 88 & 85 & 81 & 83 & 86 \\
\hline
\end{tabular}

Author, 2018

Heat index of extreme danger (over $54.4^{\circ} \mathrm{C}$ ) could result to heat waves. The city and its environs have attained heat index danger level $\left(41-54^{\circ} \mathrm{C}\right)$ of possible heat stroke. Young children are generally in more danger due to factors including larger skin surface relative to their small bodies, higher heat production as a result of exercise 
and typically sweating less than adults. Also, children are often less aware than adults of the need to rest and rehydrate. Thirst is a late sign of dehydration, and it is important to remain hydrated, particularly before, during and after outdoor activities, especially those involving heavy physical exertion. In addition to children, people with certain conditions including, the elderly, obesity, diabetes, heart disease, cystic fibrosis and mental retardation are at greater risk of overheating and dehydration (Ana et al, 2013; United States Occupational Safety and Health Administration [USOSHA], 2018; Environmental Protection Agency, 2016; Nwaerema and Edokpa, 2019).

\section{Discussion}

This study significantly demonstrates the geo-spatial heat index and human comfort analysis of Port Harcourt city as good approach to environmental health care delivery. The results ascertained that high residential/commercial and administrative/industrial areas of the city were more vulnerable to severe health hazards as they have greatly exceeded the human comfort threshold of $27^{\circ} \mathrm{C}$ indicating that those living in these sections of the city would relatively suffer more of exhaustion, fatigue and heat stroke. The findings showed that dangerous heat index $\left(>41^{\circ} \mathrm{C}\right)$ were common in the late dry season of January, February and March with possible greater heat hazards on children and elderly. Heat stress is a condition that the body cannot cool down properly through sweating which results to rising body temperature and may damage the brain and other important organs. Heat stress can cause dehydration which is a big risk to adults and children. Symptoms of heat stress include hot and dry skin, paleness, rapid heart rate, muscle cramps, nausea and vomiting, disorientation and confusion, delirium, fainting or coma, worsening of pre-existing medical conditions. Children's body surface area makes up a much greater proportion of their overall weight than adults; therefore they suffer dehydration at $2 \%$ loss of body water. The elderly at 65 years and above are vulnerable to heat related illness due to their weak body organs and inability to adapt to heat stress as well as their already existing ailments accompanying old age. Thus, rural and recreational sites had relatively possible thermal performance due to their unique vegetal cover and water bodies. It is recommended that city planners and development practitioners should implement urban greening policy of tree planting and proactive management of residential/commercial and administrative/industrial areas without further delay in order to cushion the deadly menace of urban heat stress in Port Harcourt city, Nigeria.

\section{References}

Almeida, S., Casimiro, E., \& Calheiros, J. (2010). Effects of apparent temperature on daily mortality in Lisbon and Oporto, Portugal. Environmental Health, 9(12), 1-7. https://doi.org/ 10.1186/1476-069X-9-12.

Ana, M., Vania, C., Sara, V., \& Carlos, S. (2013). The accuracy of the heat index to explain the excess of mortality and morbidity during heat waves - a case study in a Mediterranean climate. Bulletin of Geography. Socioeconomic Series, 20, 71-84. Retrieved from http://www.bulletinofgeography.umk.p1/20_2013/05_Monteiro.pdf.

Anderson, G. B., \& Peng, R. D. (2012). Weathermetrics: Functions to convert between weather metrics (R package). Retrieved from http://cran.r-project.org/web/packages/weathermetrics/index.html.

Andre, S. N, Joao, P. C., Mattheos, S., \& Andreas, M. (2018). Approaches to Outdoor Thermal Comfort Thresholds through Public Space Design: A Review. Atmosphere, 9(108), 2-49. https://doi.org/ 10.3390/atmos9030108

Brooke, A. G., Michelle, L. B., \& Roger, D. P. (2013). Methods to Calculate the Heat Index as an Exposure Metric in Environmental Health Research. Journal of Environmental Health Perspective, 121(10), 1111-1119. https://doi.org/ 10.1289/ehp.1206273.

Calculator.net (2018). Available from: https://www.calculator.net/dew-point-calculator.ht.

Cândido, C., deDear, R., \& Lamberts, R. (2011). Combined thermal acceptability and air movement assessments in a hot humid climate. Building and Environment, 46(2), 379-385. Retrieved from https://escholarship.org/uc/item/78v8055h.

Center for Disease Control \& Prevention [CDCP] (2006). Extreme Heat: A Prevention Guide to Promote Your Personal Health and Safety. Retrieved from http://emergency.cdc.gov/disasters/extremeheat/heat_guide.asp.

Chiadikobi, K. C., Omoboriowo, A. O., Chiaghanam, O. I., Opatola, A. O., \& Oyebanji, O. (2011). Flood Risk Assessment of Port Harcourt, Rivers State, Nigeria. Advances in Applied Science Research, 2(6), 287-298. Retrieved from www.pelagiaresearchlibrary.com.

Coseo, P., \& Larsen, L. (2014). How factors of land use/land cover, building configuration and adjacent heat sources and sinks explain Urban Heat Island in Chicago. Landscape and Urban Planning, 125, 117-129. https://doi.org/ 10.1016/j.landurbplan.2014.02.019.

Dpcalc.org (2018). Retrieved from www.dpcalc.org. 
Edokpa, D., \& Nwaerema, P. (2019). Boundary Layer Turbulence and Urban Heat Variability in the Coastal City of Port Harcourt, Nigeria. American Journal of Environment and Sustainable Development. American Journal of Environment and Sustainable Development, 4(2), 77-83. Retrieved from http://www.aiscience.org/journal/ajesd.

Edokpa, D. O., \& Nwagbara, M. O. (2017). Atmospheric Stability Pattern over Port Harcourt, Nigeria. Journal of Atmospheric Pollution, 5(1), 9-17. 2017. https://doi.org/ 10.12691/jap-5-1-2.

Environmental Protection Agency (2016). Climate Change and Extreme Heat: What You Can Do to Prepare. Retrieved from https://www.epa.gov/sites/production/files/2016-10/documents/extreme-heat-guidebook.pd.

Harlan, S. L., Brazel, A. J., Prashad, L., Stefanov, W. L., \& Larsen, L. (2006). Neighborhood microclimates and vulnerability to heat stress. Soc Sci Med., 63(11), 2847-63.

James, W. (2002). Green roads: research into permeable pavers. Stormwater, 3(2), 48-40. Retrieved from https://www.dri.edu/images/stories/editors/leapfrog/techprog/Vh_2_Watson.pdf

Ketterer, C., \& Matzarakis, A. (2014). Human-biometeorological assessment of the urban heat island in a city with complex topography - The case of Stuttgart, Germany. Urban Climatology, 10, 573-584. https://doi.org/ 10.1016/j.uclim.2014.01.003.

Khaled, E. A. (2011). Thermal Comfort Prediction, Conditions and Air Quality for Younger and Older Children in Kuwait Schools. Published Thesis. Loughborough University's Institutional Repository. Retrieved from https://dspace.lboro.ac.uk/2134/9456

Mark, G. L. (2005). The Relationship between Relative Humidity and the Dewpoint Temperature in Moist Air: A Simple Conversion and Applications. Bulletin of the American Meteorological Society, 86(2). https://doi.org/ 10.1175/BAMS-86-2-225.

Monteiro, A., Carvalho, V., Velho S., \& Sousa, C. [2011]. Assessing and monitoring urban resilience using COPD in Porto. In Science of the Total Environment, 414, 113-119. https://doi.org/10.1016/j.scitotenv. 2011.11.009.

National Centre for Environmental Prediction (NCEP), National Weather Service, (2018). Meteorological Conversions and Calculations: Heat Index Calculator. Retrieved from https://www.wpc.ncep.noaa.gov/html/heatindex.shtml.

Nwaerema, P., \& Edokpa, D. (2019). Regional Assessment of Population and Warming of a Tropical Country, Nigeria, from 2006 to 2036. Environmental and Earth Sciences Research Journal, 6(1), 1-25. https://doi.org/10.18280/eesrj.060101.

Nwaerema, P., \& Nwagbara, M. O. (2018). Spatial and Temporal Variability of Weekday Urban Heat Island in Port Harcourt Metropolis and Environs. The International Journal of Science and Technoledge, 6(3), 127-136. wwww.theijst.com.

Nwaerema, P., Ologunorisa, T. E., Nwagbara, M. O., \& Ojeh, V. N. (2019). Geo-Spatial Dynamics of Land Surface Temperature of Port Harcourt Metropolis and Environs from 1986 to 2018: Implication for Heat Disaster Management. Earth Sciences, 8(3), 169-177. https://doi.org/10.11648/j.earth.20190803.15.

Nwaerema, P., Ojeh, N. V., Amadou, C., \& Atuma, I. N. (2019). Spatial Assessment of Land Surface Temperature and Emissivity in the Tropical Littoral City of Port Harcourt, Nigeria. International Journal of Environment and Climate Change, 9(2), 88-103. https://doi.org/ 10.9734/IJECC/2019/v9i230099.

Ponni, M., \& Baskar, R. (2015). A Study on Indoor Temperature and Comfort Temperature. International Journal of Engineering Science Invention, 4(3), 7-14. Retrieved from http://www.ijesi.org/v4i3(version-1).html.

Ronald, H. H., William, J. C., \& Harry, J. S. (2010). Principles of Heating, Ventilating and Air-Conditioning, 6th edition, American Society of Heating, Refrigerating and Air-Conditioning Engineers. Retrieved from https://www.scribd.com/document/368155943/Principles-of-Heating-Ventilating-and-Air-Conditioning-8th$\mathrm{Ed}$.

Sarah, O., Lee, S., Kate, H., Phong, T., Lan, H., \& Phuong, H. N. (2016). Heat index trends and climate change implications for occupational heat exposure in Da Nang, Vietnam. Elsevier. Science Direct, 2(3), 41-51. https://doi.org/10.1016/j.cliser.2016.08.001.

Shaibu, V. O., \& Utang, P. B. (2013). Human comfort and the microclimatic drivers across different land use types in Port Harcourt metropolis, Nigeria. Ethiopian Journal of Environmental Studies and Management, 6, 1-10. https://doi.org/10.4314/ejesm.v6i6.4S. 
Stewart, D. (2011). A systematic review and scientific critique of methodology in modern urban heat island literature. International Journal of Climatology, 31, 200-217. https://doi.org/10.1002/joc.214.

Stone, B. (2012). The city and the coming climate. Climate change in the places we live. New York, NY. Cambridge University Press. Retrieved from admin.cambridge.org/...climate-change/city-and-coming-climate-climatechange-plac.

Sushil, K. D., Sagnik, D., Popat, S., Mamta, D., Vaishali, S., Sourangsu, C., \& Rohit, K. C (2017). Comparative Study of Heat Indices in India Based on Observed and Model Simulated Data. Current World Environment 12(3), 504-520. https://doi.org/10.12944/CWE.12.3.04.

\section{Copyrights}

Copyright for this article is retained by the author(s), with first publication rights granted to the journal. This is an open-access article distributed under the terms and conditions of the Creative Commons Attribution license (http://creativecommons.org/licenses/by/4.0/). 